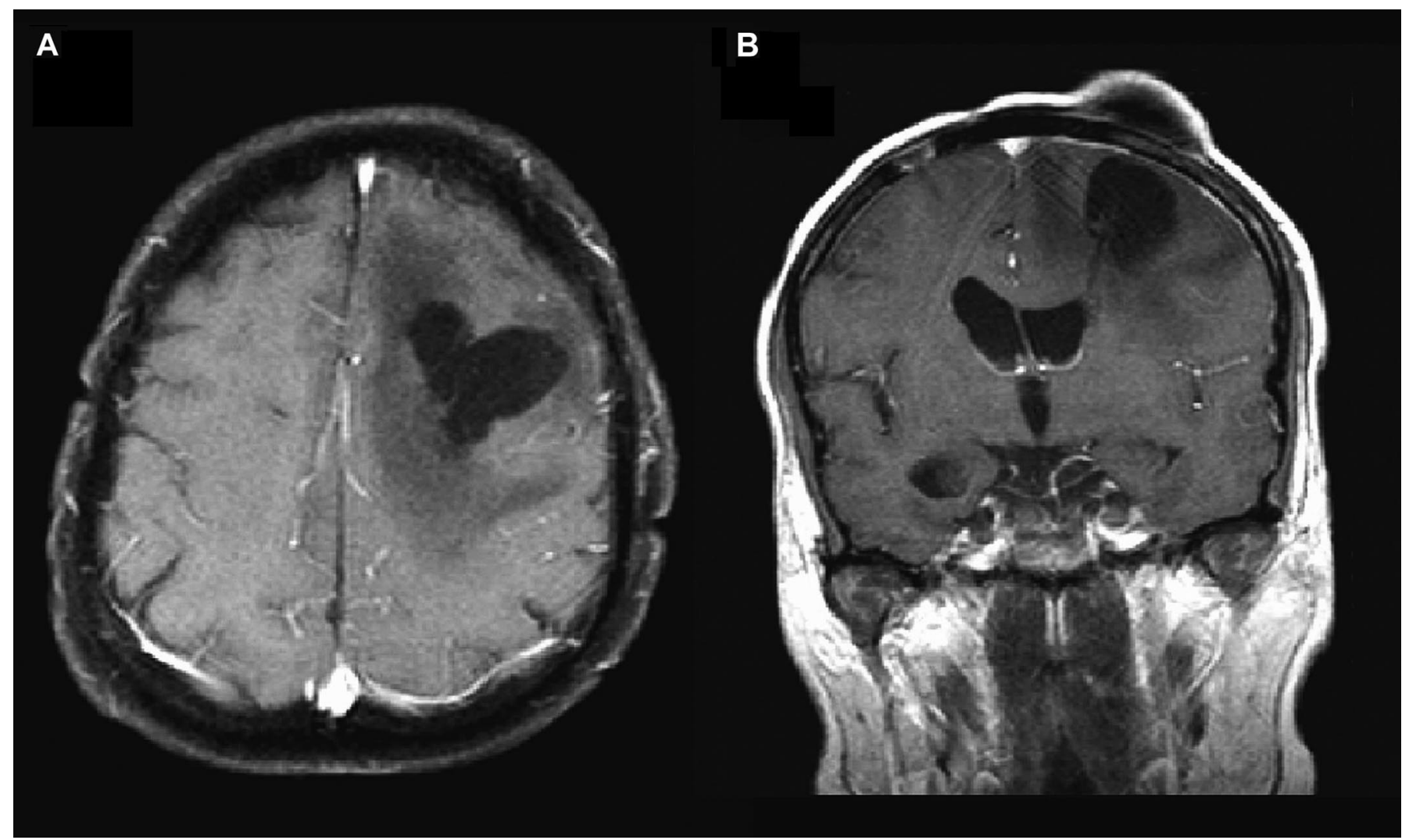

Figure. (A) T1-weighted axial MR image with contrast demonstrates a nonenhancing left frontal cystic cavity surrounding the intraventricular catheter with marked surrounding edema. (B) T1-weighted coronal MR image with contrast again depicts the cystic cavity with mass effect. Note the Ommaya reservoir placement and lumen of the intraventricular catheter traversing the cystic cavity.

\section{Methotrexate-induced encephaloclastic cyst: A complication of intraventricular chemotherapy}

Sajeel Chowdhary, MD; Lisa M. Chalmers; and P.A. Marc Chamberlain, MD, Tampa, FL

A 36-year-old man with acute lymphoblastic leukemia developed recurrence treated with busulfan and fludarabine followed by transplantation.

Disease recurred as leukemic meningitis for which an Ommaya reservoir was placed. Following his sixth intraventricular methotrexate treatment, the patient developed acute confusion and a

Disclosure: The authors report no conflicts of interest.

Address correspondence and reprint requests to Dr. Sajeel Chowdhary, H Lee Moffitt Cancer Center, University of South Florida, Department of Interdisciplinary Oncology, MCCNEURPROG, 12902 Magnolia Drive, Tampa, Florida; e-mail:chowdhsa@moffitt.usf.edu right hemiparesis. Cranial MR (figure) revealed an encephaloclastic cyst as a complication of intraventricular chemotherapy with methotrexate via an Ommaya reservoir.

The reservoir was removed and the cyst contents revealed by histopathology an inflammatory admixture of lymphocytes and macrophages. Cyst contents were bacteriologically sterile and the cyst was negative for malignancy. Subsequently, the patient made a complete neurologic recovery.

Ommaya reservoirs are frequently used to deliver intraventricular chemotherapy in cancer patients with leptomeningeal metastases. ${ }^{1}$ Methotrexate-induced encephaloclastic cyst is an infrequently described complication of intraventricular chemotherapy among other complications such as aseptic (chemical) meningitis and catheter-related infections. ${ }^{2}$ Etiopathogenesis is presumed to be due to retrograde flow along the catheter tract of the intended intraventricular chemotherapeutic.

1. Sandberg DI, Bilsky MH, Souweidane MM, Bzdil J, Gutin PH. Ommaya reservoirs for the treatment of leptomeningeal metastases. Neurosurgery 2000;47:49-55.

2. Chamberlain MC, Kormanik PA, Barba D. Complications associated with intraventricular chemotherapy in patients with leptomeningeal metastases. J Neurosurg 1997;87:694-699. 


\section{Neurology}

\section{Methotrexate-induced encephaloclastic cyst: A complication of intraventricular chemotherapy}

Sajeel Chowdhary, Lisa M. Chalmers and P. A. Marc Chamberlain

Neurology 2006;67;319

DOI 10.1212/01.wnl.0000218285.66074.45

\section{This information is current as of July 24, 2006}

\section{Updated Information \& Services}

References

Subspecialty Collections

Permissions \& Licensing

Reprints including high resolution figures, can be found at: http://n.neurology.org/content/67/2/319.full

This article cites 2 articles, 0 of which you can access for free at: http://n.neurology.org/content/67/2/319.full\#ref-list-1

This article, along with others on similar topics, appears in the following collection(s):

Chemotherapy-tumor

http://n.neurology.org/cgi/collection/chemotherapytumor MRI

http://n.neurology.org/cgi/collection/mri

Information about reproducing this article in parts (figures,tables) or in its entirety can be found online at:

http://www.neurology.org/about/about_the_journal\#permissions

Information about ordering reprints can be found online:

http://n.neurology.org/subscribers/advertise

Neurology ${ }^{\circledR}$ is the official journal of the American Academy of Neurology. Published continuously since 1951, it is now a weekly with 48 issues per year. Copyright . All rights reserved. Print ISSN: 0028-3878. Online ISSN: 1526-632X.

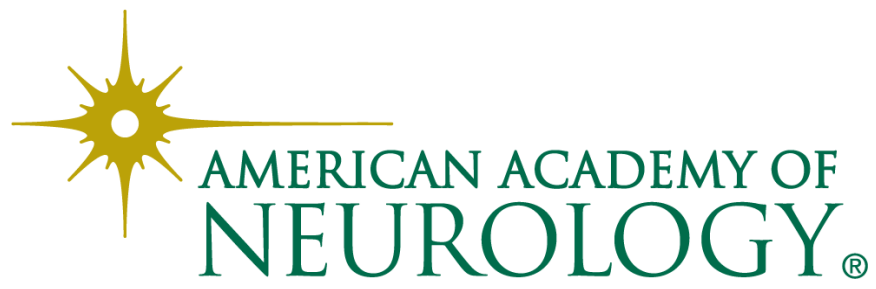

